\title{
The Archaic Forms of the Kamang Hilir Isolect of the Minangkabau Language
}

\author{
N Nadra ${ }^{1}$ \\ Faculty of Humanities, Andalas University, Padang, Indonesia ${ }^{1}$ \\ \{nadra_1963@yahoo.co.id ${ }^{1}$ \}
}

\begin{abstract}
This research describes archaic forms of the Kamang Hilir isolect of the Minangkabau language. These are forms no longer in current use but still recognized by some speakers. An inventory will preserve these forms for future studies of culture and history, preventing them from becoming lost to prosperity. The research uses observational and interview methods. The observations used discrete microphones to record oral exchanges in daily life in the Kamang Hilir district. Interviews were conducted with native speakers of the isolect. The data obtained were transcribed orthographically. A comparison was made between the forms that were recorded from spontaneous conversation and the forms elicited from the interviews to determine which forms could be considered archaic. The results found a number of archaic forms. Forms had become archaic because the object or concept was no longer used or because the form had been replaced by one from another dialect or language (with or without modification to isolect phonological rules). The development from the archaic forms into contemporary ones can be either a one or two-step process.
\end{abstract}

Keywords: archaic, Kamang Hilir isolect, development, influence, contemporary form.

\section{Introduction}

The advancement of both technology and communication can result in more rapid language change, either within the language itself or as it is influenced by outside sources. This change is clearly observable from one generation to the next and may result in the loss of certain components in a language, the appearance of new lexical components, or the replacement of one component with another. This paper will discuss the changes taking place in the Kamang Hilir isolect of the Minangkabau language from the District of Kamang-Magek, Agam Regency which is $12 \mathrm{~km}$ from the City of Bukittinggi, West Sumatra, Indonesia. There are many words and terms that have disappeared or been replaced by newer words or terms. A new word or term may arise in response to the emergence of new objects or concepts. These words are often borrowed from other languages, particularly Indonesian, other local languages, and other Minangkabau isolects, chiefly, the general Minangkabau isolect used between speakers from different isolects (Bahasa Minangkabau Umum).

In other cases, the form has become redundant as the object referred to or the concept defined is not used anymore. For example, the Kamang Hilir isolect term kapuak 'rice storage' was 
recognized and also known as a rice lumbuang. Kapuak is no longer used, thus, the form is deemed archaic. Now the rice is stored in a goni 'gunny sack' or karuang 'sack' and both these forms are in active usage. Similarly, padati 'cart' is a wagon pulled by a buffalo. These wagons are no longer used so the term padati is also categorized as archaic. To prevent loss of cultural heritage an inventory of such forms is being compiled by the authors. This research is part of the documentation of this process.

Various linguistic aspects of the Minangkabau language have been extensively studied for a variety of purposes. In the past, Nothofer[1] attempted to reconstruct Proto Malayo-Javanic and[2] did the same for Proto Malayic. The present author has researched both innovative and conservative dialects of Minangkabau language[3], reconstructed a proto-language[4], retraced the geographic origin and migration direction[5], and discussed Minangkabau language with respect to language and identity[6]. Nadra[7] have also studied the Minangkabau lexicon related to food (including verbs and nouns related to ingredients). Wahyuni et al., have discussed numeral classifiers used in local Minangkabau wisdom from the Halaban Isolect of Lima Puluh Kota[8] and from Tanah Datar isolect [9].

The Kamang Hilir isolect of the Minangkabau language used on WhatsApp by the group members of Kamang Saiyo Bagurau has been investigated [7], [10]. The results of this research indicated that WhatsApp may serve as a tool for language maintenance.

Isolects are not static. Change can be slow or rapid[5], [11]. One of the causes of the change is the speakers of the isolect concerned. If the speakers do not have pride in their isolect and consider that the other isolects are better, they will switch to the isolect they consider better. Based on my experience, some speakers are ashamed to use their own isolect feeling it to be obsolete.

Another influence in isolect change is migration, which in the Minangkabau culture is referred to as marantau. Usually, the emigrating Minangkabau will adjust their language to the one spoken in the host area. If they migrate within the Minangkabau region (marantau di subaliak dapua or 'local migration') they will tend to use a general form of the Minangkabau language and rather than using their regional characteristic forms.

The disappearance of certain forms such as words and terms referred to here in this paper is not that caused by migration but rather by the disappearance of certain objects or concepts due to the influence of another dialect or language, mainly, the national Indonesian language.

\section{Research Method}

Oral data used in this research was acquired from observation of language daily use and from interviews with native speakers living in Kamang Hilir district. The interview is used to find out the archaic forms. The use of recordings from daily life is referred to as the observational method whereas the interview process is referred to as the conversing method. Both sets of data were transcribed orthographically.

Then, the obtained data were analyzed by comparing the two sets of data. Forms not found in daily life but still recognized by the speaker are classified as archaic. In this article, the archaic form is marked $\operatorname{Arc}($ haic) and is listed first and followed by the equivalent contemporary (modern) form, marked Con(temporary), then by an English explanation. 


\section{Result and Discussion}

Based on the result of both interview and data analysis, the archaic forms of Kamang Hilir isolect include:

mancutu 'to muse on'

The form mancutu 'to muse on' is an archaic form. However, such a form is still recognized by the speakers over 50 years old. The form used currently is tamanuang 'to muse on'. Such forms appear in data 1 as follows:

Data 1: Lah mancutu sen no duduak di sinan.

(Arc.)

Lah tamanuang sen inyo duduak di sinan.(Con.)

'S/he sat musing over there.'

The form tamanuang 'to muse on' based upon the interview with the speakers of Minangkabau isolect of Kamang Hilir, is a new form.

kicin 'small'

The form kicin 'small' is not found nowadays being replaced by the form kicik 'small' and then replaced again by kaciak 'small'. However, kicin and kaciak are still recognized by the speakers over 50 years old. This can be seen in the following the example below.

Data 2: Badanno kicin bana, tasalek sen. (Arc. 1)

Badanno kicik bana, tasalek sen. (Arc. 2)

Badanno kaciak bana, tasalek sen. (Con.)

'His/her body is very small, he/she gets squashed in a crowd.'

3) bapiriak 'to get pinched'

Formerly, the form bapiriak was used to refer to 'to get pinched' This was derived from piriak 'to pinch hard with twisting' and the ergative prefix $b a$ - but is no longer used but replaced by the form bapiciak 'to get pinched' derived from piciak 'to pinch' and plus the ergative prefix ba-. Such forms may be seen in data 3 as follows:

Data 3: Bapiriak amuahno talingono. (Arc.)

Bapiciak amuahno talingono. (Con.)

'His/her ear(s) should be pinched.

4) kulikat 'behavior'

The form kulikat 'behavior', or sometimes the recent variation kalikat, are no longer used so categorized as archaic. Parangai is used to replace it. Look at the examples below.

Data 4: Ganjia bana kulikat paja 'tu. (Arc.)

Ganjia bana parangai paja 'tu. (Con.)

'That boy's behavior's very odd.'

5) (ka)kiun '(to go) there'

In the Kamang Hilir isolect, the form kiun or ka kiun meaning (to go) there is no longer used. Ken used to be used instead. The ken form, however, is now only spoken by over 50-yearold speakers. The more common contemporary spoken form is ka sinen 'to go there'. See the following example:

Data 5: Kiun den beko. (Arc. 1)

Ken den beko. (Arc. 2) 
Ka sinen den beko. (Con.)

'I will come there later.'

6) sangkek tu 'at that time'

One of the forms used to tell the time in the Kamang Hilir isolect was sangkek tu 'at that time'. However, such a form is rarely used now. Wakatu tu 'at that time' is more common. The form wakatu 'time' is loaned from Arabic via the Indonesian waktu 'time' then adjusted to the sound pattern of the Kamang Hilir isolect that it does not recognize close-knit sequences of consonants by inserting a vowel sound between the ' $k$ ' and the ' $t$ '. Such a form is found in data 6) as follows:

Data 6: Sangkek tu wakno nan pai. (Arc.)

Wakatu tu wakno nan pai. (Con.)

'At that time it was him/her that left.'

7) cek piah 'a hundred'

The form cek piah meaning Rp 100.00 (one hundred rupiahs) using an abbreviation 'cek' for 'ciek' (one) and the contracted form piah for rupiah is no longer used but the form saratuh (rupiah) is used instead. See the example below:

Data 7: Aragono cek piah sakabek. (Arc.)

Aragono saratuh sakabek. (Con.)

'The price is Rp 100.00 a bunch.'

Other archaic forms for money include sasuku 'Rp 50.00'; saringgik 'Rp 250.00'; and limo rupiah 'Rp 500.00.' being replaced by; limo puluah rupiah, duo ratuh limo puluah rupiah and limo ratuh rupiah respectively.

8) baruah 'down'

In the Kamang Hilir isolect, there were two forms for the direction down, baruah 'down' or 'downhill' and ilia 'lower' or 'downstream'. These are not used anymore except in place names such as Kamang Ilia 'Kamang Hilir' and Bara Bukik derived from Baruah Bukik 'Below the Hill'. Such forms have been replaced with place names like Ladang Darek, Dangau Baru, and Cegek whereas for direction, loan forms borrowed from Malay are used such as ka timur 'to the east'; ka barat 'to the west; and ka utara 'to the north'. This use may be seen in the examples as follows:

Data 8: Wak dek ka ka baruah sabanta. (Arc.)

Waden ka ka Ladang Darek sabanta. (Con.)

'I am going to the Ladang Darek for a while.'

In the example above, Ladang Darek is a proper noun of a place whereas use for direction may be seen in the following example below:

Data 9: Latakno arah ka baruah.(Arc.)

Latakno arah ka selatan. (Con.)

'It is located to the south.' (depending on the geography of the location)

9) kapuak 'rice storage (barn)'

In the Kamang Hilir Isolect, the term kapuak was used for 'rice storage barn'. However, the forms used now are goni 'gunny sack' or karuang 'sack'. The change from kapuak to goni or karuang is due to the change of the form of storage as rice barns are no longer used. See the examples below: 
Data 10: Padino talatak di kapuak. (Arc.)

Padino talatak di goni/karuang. (Con.)

'His/her rice is stored in the gunny sack.'

10) padati 'cart'

The form padati 'cart' means a wagon pulled by a buffalo. This means of transportation has been replaced by the motorbike, truck or car. Hence, the lexicon padati has automatically disappeared to be replaced by words such as onda 'motorbike' from the Japanese brand name 'Honda' and oto 'car'. See the example below:

Data 11: Baban tu dibao jo padati. (Arc)

Baban tu dibao jo oto. (Con.)

'The load is transported with a buffalo cart/car.'

11) darok 'state', 'situation'

The form darok meaning 'state', 'situation' is an archaic form. Now Kamang Hilir isolect speakers use angin instead. An example may be seen as follows:

Data 12: Caliak darok dulu, Pak. (Arc.)

Caliak angin dulu, Pak. (Con.)

'Let's see the situation first, Sir.'

12) $m e k$ 'very'

The form mek 'very' in kuek mek meaning 'very strong' or 'truly strong' is no longer used and the form bana 'true' is used instead. The form mek serves as an intensifier for the word kuek 'strong'. See the following example.

Data 13: Pakiak si Del kuek mek iah Da, takajuk wak. (Arc.)

Pakiak si Del kuek bana yo Da, takajuk wak. (Con.)

'Del's scream is very loud, isn't it? We were startled.'

13) buntiang 'pregnant'

In the past, the form used to refer to pregnancy in the Kamang Hilir isolect was buntiang. Then, the constituent mangandung 'to conceive' was used instead. However, the form manganduang is now only used by the speakers over 50 years old. Younger speakers use hamil 'pregnant' instead, a word loaned from Indonesian. It is clearly a loan form since it does not follow the sound pattern of the Kamang Hilir isolect. It ends with a /1/ which is not a Kamang Hilir isolect sound pattern. Normally for a word to be absorbed entirely, any final /-1/ position will undergo deletion, e.g. taba < tebal 'thick', banta < bantal 'pillow', and samba < sambal 'condiment'. However, in this case, the ' 1 ' is retained indicating the word does not yet have the status of a truly Kamang Hilir isolect term. See the following example below:

Data 14: Wakno muntah-muntah dek buntiang. (Arc. 1)

Wakno muntah-muntah dek manganduang. (Arc. 2)

Wakno muntah-muntah karano hamil. (Con.)

'She kept vomiting because of her pregnancy.'

14) bacaran 'to quarrel' 'fight with words'

The form bacaran was used to refer to quarreling parties shouting at each other angrily. This is no longer used, being replaced with batangka 'to quarrel'. An example may be seen as follows:

Data 15: Karajono bacaran sen tiok ari. (Arc.) Karajono batangka sen tiok ari. (Con.) 
'S/he kept quarreling every day.'

15) saik 'slice'

The form saik means 'to slice' in the Kamang Hilir isolect. It is used, not only for tiny and thin objects such as onion or garlic slices, but it is also used for other things such as mango, papaya, apple, and bread. This form is beginning to disappear. A new form irih 'to slice' replaces the word saik. See the following examples obtained in the field.

Data 16: Gadangan saketek saik dagiang tu. (Arc.)

Gadangan saketek irih dagiang tu. (Con.)

'Make the meat slice a little bigger.'

16) sakaciak 'a little'

In the Kamang Hilir isolect, the word sakaciak meant 'a little' but is no longer used. Such a form is still recognized by the speakers especially those over 50 years old. The more contemporary word is saketek 'a little' see the following example.

Data 17: Sakaciak no asia sawah tu. (Arc.)

Saketek no asia sawah tu. (Con.)

'What a small harvest from the (wet) rice field.'

The present study shows that the archaic forms were found in the Kamang Hilir isolect. The reason was in some cases perhaps due to the disappearance of the use of certain objects or concept the words signified. These have often been replaced by new objects or new concepts, resulting from the advancement of technology and better communication. For example: kapuak 'rice storage barns' have been replaced by karuang 'sack' or goni 'gunny' and padati 'buffalo cart' by honda 'motorcycle' or oto 'car' and every-day use of the language reflects these changes.

Wider communication with the world outside due to mass media and ease of travel also facilitates external sources of language influencing the Kamang Hilir isolect with adjustment to the isolect phonological rules such as insertion of vowel sounds to break up consonant clusters as in 'wakatu' from waktu 'time' or dropping final consonant sounds as in 'banta' from bantal 'pillow'. Sometimes, however, words retain the pronunciation of the original language in which case they remain loan words. The word hamil is an example of this.

The development from the archaic forms the Kamang Hilir isolect to newer words or those borrowed from modern Indonesian may be a one or two-step process. Words going through a single change include mancutu 'to muse on' became tamanuang; sangkek tu 'at that time' became wakatu tu; cek piah ' $\mathrm{Rp} 100.00$ ' became saratuh. Words undergoing a two-phase development include: kicin 'small' became kicik then became kaciak; (ka) kiun '(to go) there' became $(\mathrm{ka}) \mathrm{ken}$ then became $\mathrm{ka}$ sinen; and buntiang 'pregnant' became manganduang then became hamil.

\section{Conclusions}

A number of archaic forms were found in the Kamang Hilir isolect. The reason was in some cases perhaps due to the disappearance of the use of certain objects or concept the words signified. These have often been replaced by new objects or new concepts, resulting from the advancement of technology and better communication. Wider communication with the world outside due to mass media and ease of travel also facilitates external sources of language influencing the Kamang Hilir isolect. The development from the archaic forms into modern ones can be either a one or two-step process. 
The Kamang Hilir isolect continues to change rapidly. Documentation of previous forms not only preserves them for posterity but also help researchers understand the evolution process of isolects in general.

\section{Acknowledgments}

This paper is a part of my research titled Bentuk-bentuk Arkais dalam Bahasa Minangkabau Isolek Kamang Hilir (The Archaic Forms of the Kamang Hilir Isolect of the Minangkabau language). The completion of this research was aided by the financial help from the Faculty of Humanities, Andalas University sourced from the Faculty's PNBP. The researcher is grateful to all parties responsible for funding. The same gratitude is also delivered to all the parties who helped the researcher bring the research and the article into reality, especially, to the informants who provided the data for this research.

\section{References}

[1] B. Nothofer, The Reconstruction of Proto-Malayo-Javanic. BRILL, 1975.

[2] K. A. Adelaar, Proto Malayic: The reconstruction of its phonology and parts of its lexicon and morphology. Canberra: Research School of Pacific Studies, the Australian National University, 1992.

[3] Nadra, "Geografi Dialek Bahasa Minangkabau," J. Ilm. Ilmu-Ilmu Hum., vol. 3, no. 1, 2000.

[4] Nadra, Rekonstruksi Bahasa Minangkabau. Padang: Andalas University Press, 2006.

[5] Nadra, "Isolek Natal di Sumatera Utara dan Hubungannya dengan Isolekisolek Minangkabau di Sumatera Barat," Pascasarjana dan Fakultas Sastra \& Seni Rupa Universitas Andalas, 2009.

[6] Nadra, "Language and Identity: Some Cases in Minangkabau Language," in Proceeding The 2nd International Seminar on Linguistics (ISOL-2), 2015.

[7] Nadra, Kata dan Istilah Bahasa Minangkabau yang Digunakan dalam Whatsappo oleh Anggota Grup Kamang Saiyo Bagurau,. Padang: Andalas University Press, 2016.

[8] S. Wahyuni, N. Nadra, and R. Febrina, "The Minangkabau local wisdom in numeral classifier for food ingredient counter case of Halaban isolect, Lima Puluh Kota district," in nternational Seminar on Linguistics (ISOL-3): Language and Social Change, 2017.

[9] S. Wahyuni, Nadra, and R. Febrina, "The Mensural Numeral Classifier Based on the Local Wisdom of Minangkabau Community at Tanah Datar Regency," Int. J. Linguist., vol. 9, no. 5, 2017.

[10] Nadra, "Word and term of Minangkabau language used on Whatsapp," in ADRI International Multidiciplinary Conference and Call for Papers 7th, 2017.

[11] Ayatrohaedi, Dialektologi Sebuah Pengantar. Jakarta: Pusat Pembinaan dan Pengembangan Bahasa, 1979. 